which we may infer that the Hindus were aware not only of the therapeutic virtues of mercurials, but had recognised their remarkable antiseptic and preservative properties. In fact, according to Dr. Rây, the history of Hindu chemistry is emphatically the history of the progress of chemical operations grouped round the preparations of mercury. So much is this the case that in ascertaining the age of a medical work or of a chemical Tantra it may be laid down as a fairly safe guide whether any mention of the use of mercury occurs in it, and, if so, in what particular form.

Dr. Rây gives a number of instances in which discoveries usually considered of Western origin are to be found noted in old Hindu treatises, such as those of Vrinda and Chakrapani. The Tantra, the "Rasarnava" (about I200 A.D.), is a repository of chemical lore, with elaborate directions and details of the construction of apparatus, furnaces, hearths, etc., required for distillation, sublimation, calcination, extraction of metals, etc., and shows remarkable powers of keen and accurate observation, The necessity for experiments is strictly enjoined in most of these old works, and the value of the Baconian method and of the precepts of the "experimentarian philosophers" of the Royal Society of Charles II. was long ago recognised and appreciated by their Indian predecessors. Even the influence of the experimental method on teaching was not lost sight of. "They alone," says Dhundhukanatha, "are to be regarded as real teachers who can show by experiments what they teach. They are the deserving pupils who", having learned the experiments from their teachers, can actually perform them. The rest, both the teachers and pupils, are merely stage actors."

Verily one generation passeth away and another generation cometh, and there is no new thing under the sun.

$\mathrm{T}$.

\section{THE SUPPLY OF OPTICAL GLASS AND} INSTRUMENTS.

$\mathrm{O}^{\mathrm{r}}$ PTICAL matters, and technical education generally, continue to claim their share of public attention. Following upon the article which appeared in our issue of May 6 (p. 266) on the supply of optical glass, we had the important debate, published verbatim in our last issue, on the proposed Advisory Council on Industrial Research which arose on the education estimates. More recently, on the motion for the Whitsuntide adjournment on May 19, an important speech, which was entirely devoted to optical matters, was made by Sir Philip Magnus. The speech, so far as it related to the supply of optical glass, necessarily traversed the ground covered by our article of May 6 , but added specific instances of the German "wire entanglements" woven round the optical trade.

The, speech, however, went further, and dealt with the supply of optical instruments, treating in detail the economic and educational aspects of the question. On the economic side it was laid down NO. 2378, VOL. 95] as an axiom "that what is essential to the safety of the realm must be produced within the Empire." The questions of high tariff and of a bonus on production were referred to, but the suggestion most favoured advocated that it be an enforced condition of all Government contracts that every part of the optical instruments contracted for should be made in this country. With the Government trade thus secured, it was argued that German attempts to capture the whole industry must fail.

On the educational side, the country's requirements, which are well known to our readers, were summarised, but perhaps too little was made of the necessity, which is strongly supported by leading experts, for the provision of, at least, one place where the whole range, from the lowest to the highest, of teaching in applied optics shall be available. The final suggestion made was "that a small committee should be appointed to co-ordinate the work of " the National Physical Laboratory, the Imperial College of Science and Technology, and the Technical Optics Department of the Northampton Polytechnic Institute. Sir Philip Magnus was followed by two other speakers, but the debate was interrupted by the Prime Minister's important statement regarding a Coalition Government.

Later on, Dr. Addison replied sympathetically on behalf of the President of the Board of Trade, and assured the House that the "subject was being closely attended to, and that the Government hoped at a very early date to have a comprehensive scheme to deal with this somewhat complicated and technical question."

\section{NOTES.}

We regret to announce the death, on May 23, at eighty-one years of age, of Dr. Hugo Müller, F.R.S., past-president of the Chemical Scciety.

THE death is announced, in his seventy-first year, of Dr. Joseph J. Hardy, who had held the chair of mathematics and astronomy at Lafayette College, Pennsylvania, since I89I. He was the author of "Analytic Geometry, Infinitesimals and Limits."

THE Paris correspondent of the Times announces the death of M. Pierre Martin, the inventor of the Martin process of steel manufacture. It was only last week that we announced that the Iron and Steel Institute had just conferred on M. Martin the Bessemer gold medal for I $^{1} 5$.

THE deaths are announced in Science of Prof. J.W. Seaver, for twenty-five years director of the Yale gymnasium, and professor of hygiene in the University, on May 5 , at the age of sixty years, and of $\mathrm{Mr}$. W. H. Reed, curator of the museum and instructor of geology in the University of Wyoming, noted for his collections of vertebrate fossils, who died at the age of sixty-seven years on April 24.

ThE Albert medal of the Royal Society of Arts for the current year has been awarded to Sir J. J. Thomson, for his researches in physics and chemistry, and 